\title{
EMC Characteristics of the Refrigerant Pipe-Based Transmission System
}

\author{
Toshiyasu Higuma, Non-member, Yousuke Watanabe, Student Member, Masamitsu Tokuda, Member
}

Keywords : refrigerant pipe, HF-band PLC, the moment method, LCL, radiated electric field

The low power ad-hoc RF wireless network covers the communication of appliances and sensors equipped in each room of building and home. But, some kinds of walls prevent the penetration of the wireless communication signal into the other room. We have proposed the refrigerant pipe-based transmission system, which uses refrigerant pipe of the multi air-conditioner (Fig.1). The refrigerant pipe-based transmission system expands the communication into the whole building.

The cross sectional view of a pair of refrigerant pipes is shown in Fig.2. A polyurethane-foam is wrapped around the copper-pipe concentrically as shown in Fig. 2 and the refrigerant pipes are similar to the insulated wires. Therefore, a pair of refrigerant pipes can be considered as the parallel transmission-lines for the general PLC modem.

However a pair of refrigerant pipes cannot be used to transmit signals in normal ways because they are electrically shorted at both terminals. Therefore, impedance upper such as ferrite core are covered near the both terminals to convert a pair of pipes into the insulated pair of electrical wires as shown in Fig.3.

In this paper describes EMC characteristics of the pipe-based transmission line, such as LCL (Longitudinal Conversion Loss) and leaked electric field.

A calculation and measuerment results of LCL are shown in Fig.4, and they agree with each other nearly. There are peaks resonance in over $10 \mathrm{MHz}$ in frequency characteristics, which are created by short-terminate branch pipe. Fig. 5 shows calculation results of the radiated electric field from the real scale pipe-based transmission line model. The electric field in vertical/horizontal polarization is under the EMI regulation in Japan.

The EMC characteristics of the pipe-based transmission line are

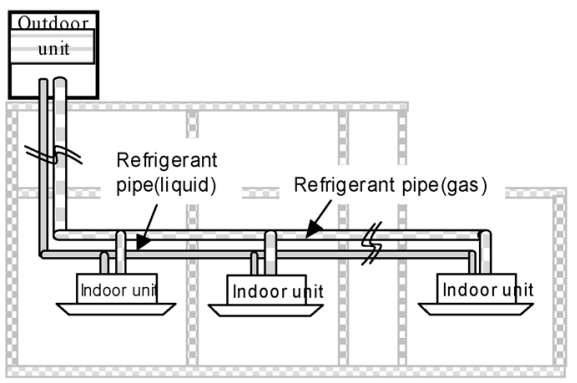

Fig. 1. Multi-type air-conditioner system

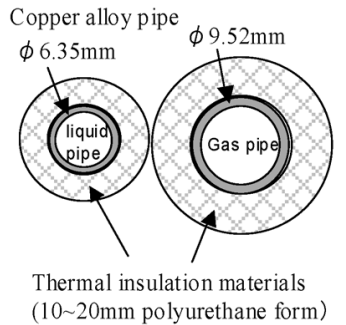

Fig. 2. Cross sectional view of refrigerant pipes calculated by using the method of moment, and it is indicative that the calculation values of the EMC characteristics almost agreed with measurement values. Furthermore, it is suggested by computer simulation of the real scale model that the pipe based transmission system has possibility to comply with the EMI regulation specified by the electrical appliance and material safety law in Japan.

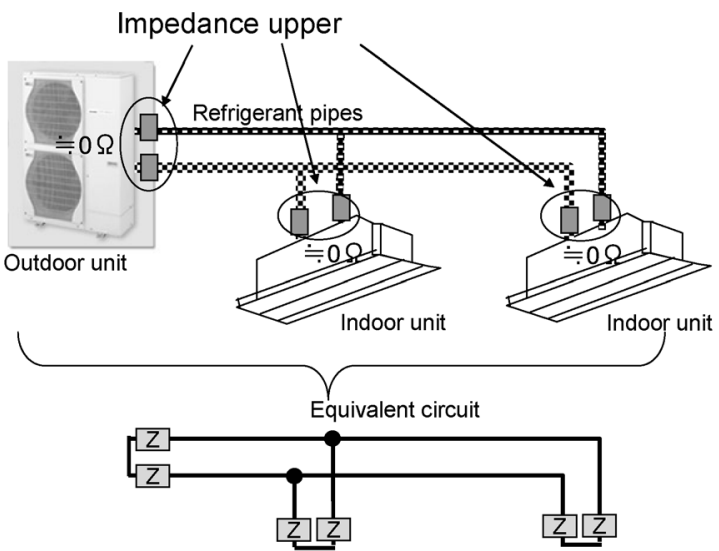

Fig. 3. Fundamental construction of pipe-based transmission

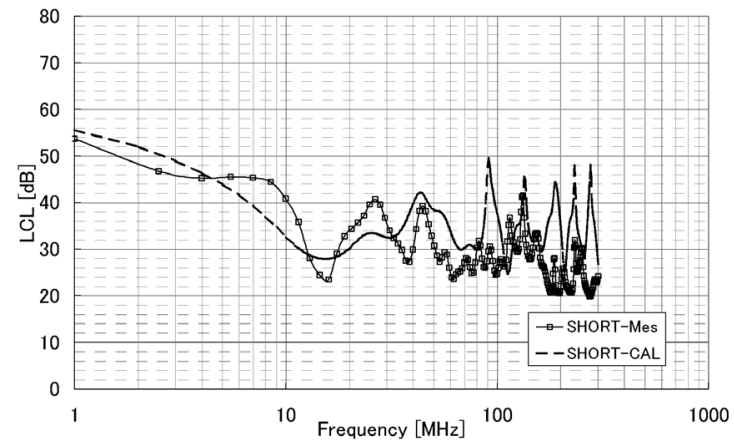

Fig. 4. Calculation result of LCL (branch condition short)

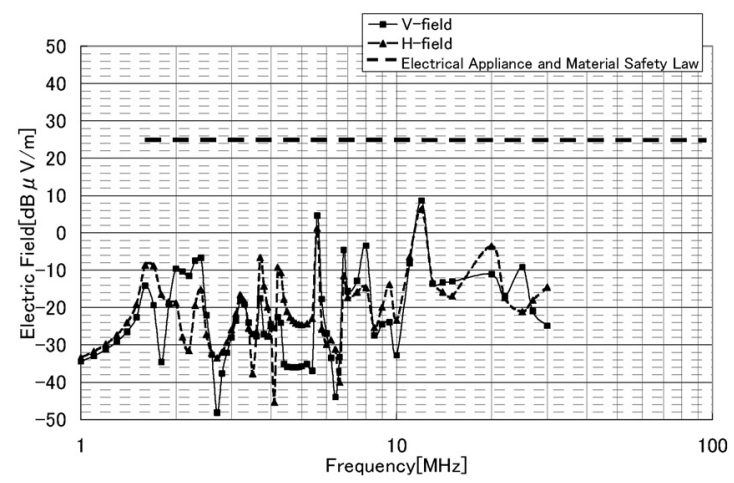

Fig. 5. Calculation result of leaked electric field in the maximum model 


\begin{abstract}
論 文

\section{空調金属配管を伝送媒体に用いた伝送システムの EMC 特性}

$\begin{array}{ll}\text { 非会員 樋熊 } & \text { 利康* 学生員 渡邊 陽介*** } \\ \text { 正 員 徳田 正満** }\end{array}$

\section{EMC Characteristics of the Refrigerant Pipe -Based Transmission System}

Toshiyasu Higuma*, Non-member, Yousuke Watanabe**, Student Member, Masamitsu Tokuda**, Member

We have proposed the pipe-based transmission system, which uses refrigerant pipe of the multi air-conditioner, and can expand the wireless communication system confined within a room space into the communication system applicable to the whole building. In this paper, EMC characteristics of the Refrigerant pipe-based transmission line, such as LCL (Longitudinal Conversion Loss) and leaked electric field, are calculated by using the method of moment, and it is clear that the calculation values of the EMC characteristics almost agreed with measurement values. Furthermore, it is suggested by computer simulation of the real scale model that the pipe based transmission system has possibility to comply with the EMI regulation specified by the electrical appliance and material safety law in Japan.
\end{abstract}

キーワード : 空調金属配管, 高周波帯 PLC, モーメント法, 平衡度, 漏洩電界

Keywords : refrigerant pipe, HF-band PLC, the moment method, LCL, radiated electric field

\section{1. はじめに}

新規配線の不要なネットワークは，施工性，経済性の面 で既築の家屋やビルなどへの管理システムに導入するのに 有効である。IEEE $802.11 \mathrm{~b} / \mathrm{g}$ や IEEE 802.15.4 など無線媒体を 用いるのも有効であるが，家屋全体，ビル全体を無線のみ でカバーすることは，間仕切壁や床，天井など構造物によ る電波の減衰により困難である。その解決手段として，筆 者等はビル用マルチエアコンの冷媒配管を無線の補完手段 として用いることを検討してきた(1)(2)。図 1 に示すように, 冷媒配管は屋外に配置される室外ユニットから屋内の各部 屋に設置される室内ユニットに液管とガス管がペアで敷設 されている。また, その断面構造を図 2 に示すが, 銅パイ プの周囲を発泡ウレタン等の絶縁体で覆った構造であり, 絶縁電線と同一の構造とみなせる。一般的なぺア線との違 いは(1)空調ユニットとの接続部において対を構成する 2 本 の冷媒配管は電気的に短絡されている，(2)両配管に流れる 冷媒の様態が異なるため, 配管径が異なっており, 線径が 異なる導体のペア線構造となっている，の 2 点である。

2006 年 10 月に, 家庭内の電灯線を情報伝送媒体として用

* 三菱電機 (株) 住環境研究開発センター

干247-8501 神奈川県鎌倉市大船 5-1-1

Mitsubishi Electric Corp. Living Environment Systems Lab.,

5-1-1 Ofuna Kamakura, Kanagawa 247-8501

** 武蔵工業大学大学院工学研究科

T158-8557 東京都世田谷区玉堤 1-28-1

Musashi Institute of Technology.,

1-28-1 Setagaya-ku,Tokyo 158-8557
い，高速ネットワークを実現する高周波帯電力線搬送通信 (HF-PLC: High Frequency - Power Line Communication) 技術 が法制化され，実用化された。2MHz から $30 \mathrm{MHz}$ の HF (High Frequency : 短波) 帯高周波信号を用いる新しい通信技術で ある(3)。EMC 対策に用いられるフェライトコアはこの帯域 で数十オームから数百オームのインピーダンスを持つ。こ のフェライトコアを用い, HF-PLC 信号周波数帯域において 冷媒配管の対を電気的に分離し，ペア線として利用可能と する配管伝送システムを筆者等が考案した。

この伝送媒体を無線と組み合わせることにより，ビル全 体をカバーする新規配線工事不要のネットワークを構築す ることが可能である。ただし線径の異なるぺア線構造のた め, 伝送線路として, 平衡度や漏洩電界について十分に検

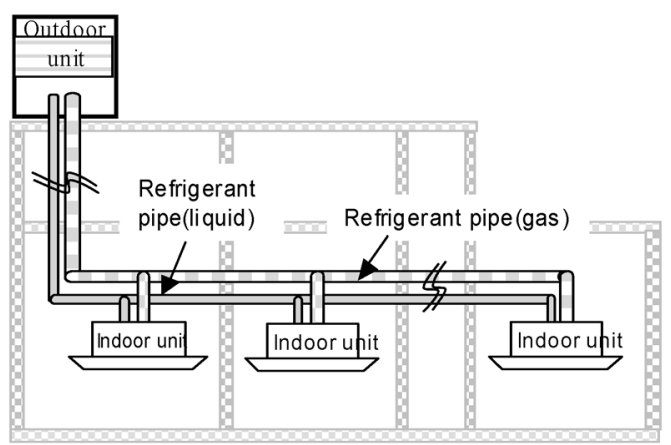

図 1 マルチタイプエアコンと冷媒配管

Fig. 1. Multi-type air-conditioner system 


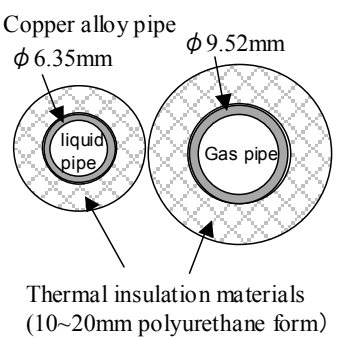

図 2 冷媒配管の断面構造例

Fig. 2. Cross sectional view of refrigerant pipes

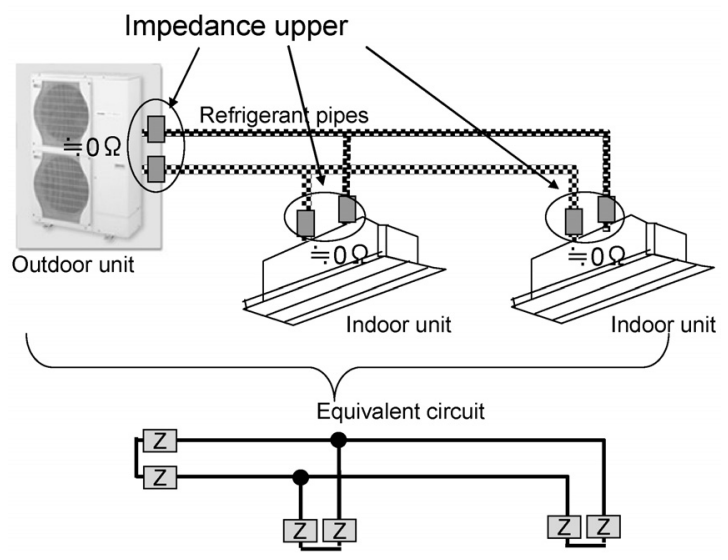

図 3 配管伝送システムの原理図

Fig. 3. Fundamental construction of pipe-based transmission

\section{討する必要がある。}

本論文では，この新しい伝送媒体に関し， LCL (Longitudinal Conversion Loss : 縦方向変換損), 漏洩電界等の $\mathrm{EMC}$ 特性，モーメント法による計算の妥当性検討，ならび にシミュレーションによる電磁環境適合性に関する検討結 果について述べる。

\section{2. 配管伝送システムの原理}

図 3 に金属配管による伝送システム（以下，配管伝送シ ステム）の原理図を示す。室内ユニットには熱交換器が内 蔵されており，配管を介して室外ユニットとの間で泠媒を 循環させることにより空調を行う。この熱交換器はアルミ 合金などの金属製であり，そこに接続される 2 本の配管は 電気的に短絡されている。また，同様に室外機においても 2 本の配管は冷媒回路の出入口で電気的に短絡されているた め, このままではディファレンシャルモードの伝送はでき ない。そのため各ユニットの配管接続部にフェライト材等 の磁性体を用いたインピーダンスアッパ Zを配し, HF 帯周 波数に於いて所定のインピーダンスを確保できるようにし ている。インピーダンスアッパには Fair-Rite 社のフェライ トコア, 型番 0461167281( 9 )を用いた。このような処理を行 うことで空調の冷媒配管は, 各分岐端を $2 Z$ で終端した伝送 線路と等価となる。

図 4 は評価に用いたンピーダンスアッパの周波数特性で

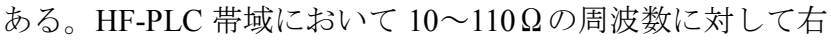

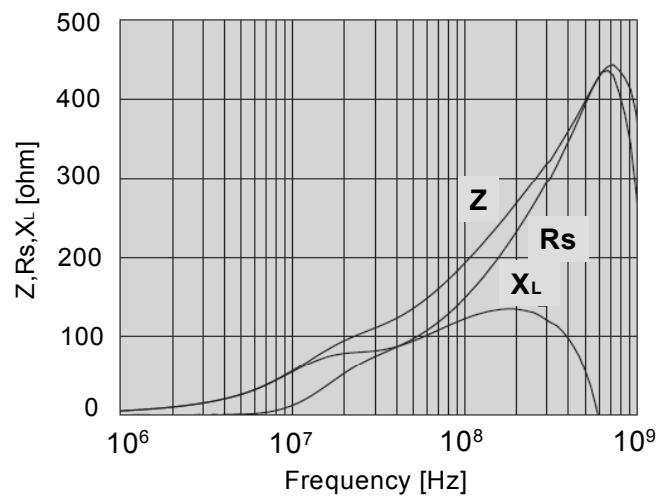

図 4 インピーダンスアッパの周波数特性

Fig. 4. Frequency characteristic of the impedance adjuster

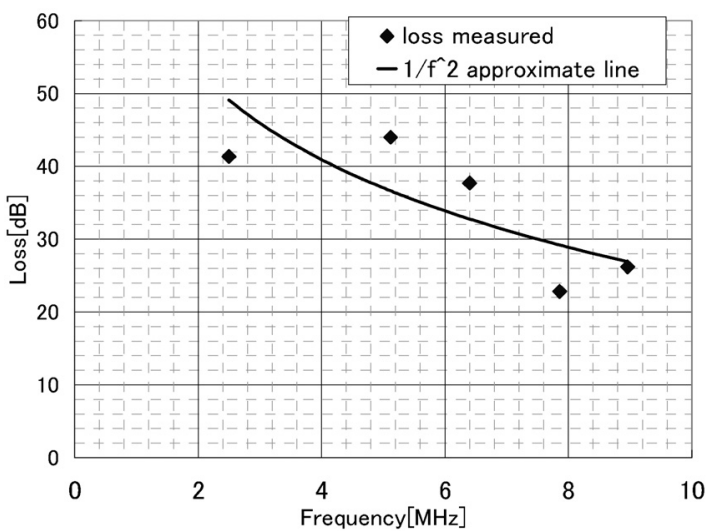

図 5 実配管の減衰周波数特性計測值 $(60 \mathrm{~m})$

Fig. 5. Measurement results of the pipe-based transmission loss in a building (length $=60 \mathrm{~m}$ )

上がりのインピーダンス特性を示している。したがって, インピーダンスアッパを取り付けた冷媒配管は HF 信号帯 域に於いて, 各ユニット端が $20 \sim 220 \Omega$ 程度のインピーダン スで終端されたペア線として機能する。

図 5 は実際のビルに設置されている空調システムの配管 にインピーダンスアッパを取り付け, 室外ユニットと最遠 端の室内ユニット間の減衰量周波数特性の計測值である。 計測対象の空調システムは室外ユニット 1 台, 室内ユニッ 卜 8 台で構成され, 室外ユニットと最遠端に配置された室 内ユニットとの図面上の直線距離は $60 \mathrm{~m}$ である。計測した 周波数範囲は 6 章に記載している Dispersed-Tone Power Line Communication (HF-DTPLC)方式( 6 )モデムの使用周波数と した。減衰計測はファンクションジェネレータに出力イン ピーダンス $5 \Omega$ のアンプを接続し $1: 1$ のトランスを介し配 管に接続した。各モデムの使用周波数毎に配管への印加電

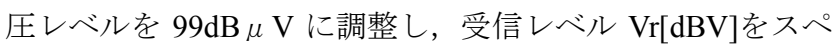
クトラムアナライザを用いて計測し, 印加した電圧值から $\mathrm{Vr}$ を減算し減衰量とした。計測した減衰量は周波数の 2 乗 にほぼ逆比例して小さくなる傾向を示す。配管を覆う断熱 材には，一般的に体積発泡率が 30 倍の発泡ポリエチレンが 用いられており, 誘電体損失は $10 \mathrm{MHz}$ で $0.01 \mathrm{~dB} / \mathrm{m}$ 程度で 
ある。したがって，配管自体の減衰量は緩い右上がりの傾 向を示すが，図 5 に示寸様に右下がりの傾向を示した。こ れはインピーダンスアッパが図 4 に示すインピーダンス特 性を持つことが要因の 1 つであると推定できる。

このように線路としての信号減衰特性については問題な く利用できる可能性を確認した。一方, 対を構成する配管 径が異なっているため, 線路の平衡度や漏洩電界について 検討を加える必要がある。次章では, 配管の平衡度を示す LCL と漏洩電界に関して, 計測とモーメント法による計算 結果の比較を行い, 計算方法の妥当性について検討を行う。

LCL, 漏洩電界の計算については 4 端子対回路網による方 法 ${ }^{(4)}$ が検討されているが, 評価対象毎にグランドとの関係を 考慮し, 一次定数を求める必要があるため, モデルの作成 が煩雑である。一方，モーメント法は計算対象の物理的形 状を入力するだけでモデルが作成でき，グランド面との関 連を含めた計算が可能であるため, 物件毎に様々なトポロ ジーをとる媒体の評価には最適であり，伝送線路として考 慮されていない電力線に関しても電界計算などの検証結果 が報告されている(5)。これら実績等も勘案して, 配管伝送シ ステムへの展開を試みた。

\section{3. 金属配管モデルの計測方法}

〈3·1〉リファレンスモデルモーメント法による LCL 計算の妥当性を評価するために, 図 6 に示す線路モデ ルを作成してリファレンスモデルとした。本モデルは $\phi$ $6.35 \mathrm{~mm}$ と $\phi 9.5 \mathrm{~mm}$ の冷媒配管を用い，長さ $4.4 \mathrm{~m}$ のメイン 配管に，長さ $3.2 \mathrm{~m}$ の分岐配管を持つ構成とした。分岐配管 の端末条件は極端な例として開放, 短絡の 2 条件としてい る。メイン配管の両端は空調ユニットによる短絡と同一条 件とするため端末を短絡した上で，インピーダンスアッパ を取り付け，その配管側に BH Electronics 社製バラン （BH040-0092，帯域幅 $1 \mathrm{MHz} \sim 650 \mathrm{MHz}$ ) を接続した。空調 用配管の屋内での敷設状況は様々であり，金属を含む躯体 壁面との距離を特定することは困難であり，実態との整合 性の検討など今後の課題である。本検討では計算の可能性 検討のため，躯体壁面との距離を $1 \mathrm{~m}$ と仮定し，また，躯体 を GND と見なして，リファレンスモデルの配管とグランド 面との距離は $1 / 10$ スケールの $10 \mathrm{~cm}$ とした。図 7 に直線部 分のメイン配管と分岐部配管の断面構造を示す。分岐接続 部でメイン配管と接触するのを防止するため， $\phi 9.5 \mathrm{~mm}$ の 冷媒配管を $10 \mathrm{~mm}$ 高く配置している。

〈3.2〉 LCL の計測方法 LCL の周波数特性は図 8 に 示す構成で測定した。送信端に接続したバランのコモンモ ードポートにネットワークアナライザから電圧 VIC を印加 し，同バランのディファレンシャルモードポートからの出 力電圧 VODの比をネットワークアナライザで計測すること により配管の LCL を測定した。配管のメイン線路端にもバ ランを接続し，コモン，ディファレンシャルの両ポートに は $50 \Omega$ の整合終端器を接続している。また, バランの筐体 は直接グランドプレーンに接地した。さらに，短絡したメ

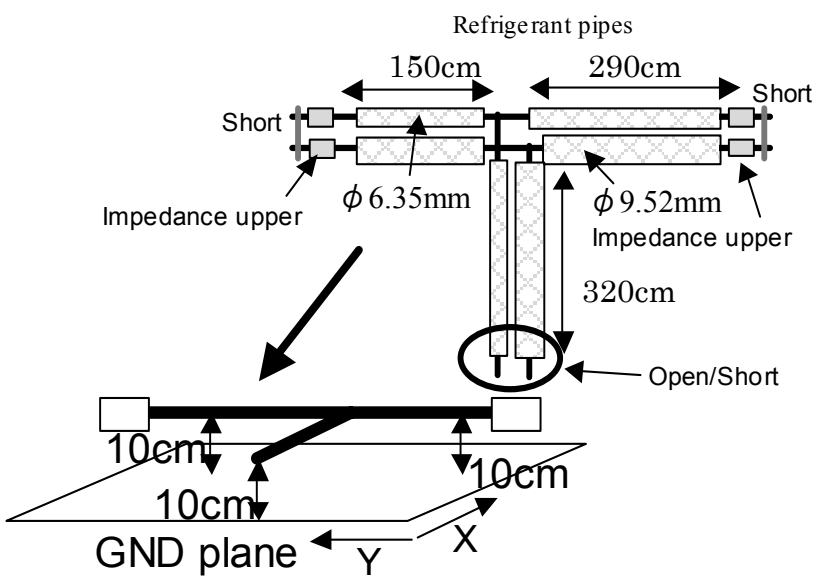

図 6 配管のリファレンスモデル

Fig. 6. Construction of the pipe-based transmission line

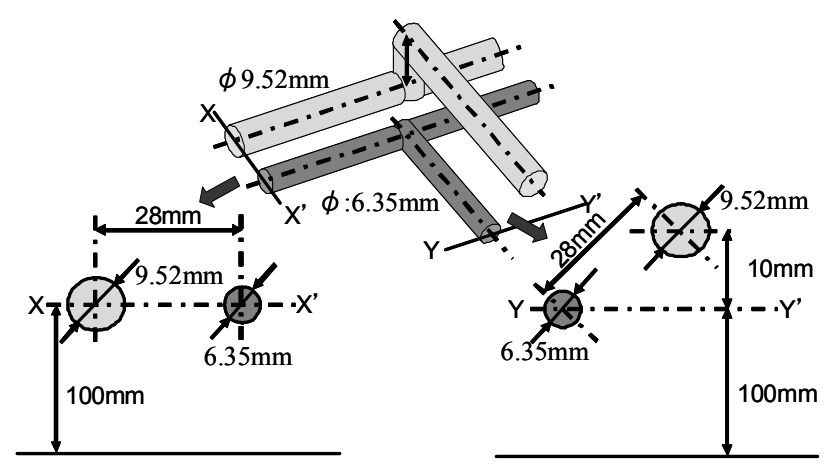

a) Main pipe

b) Brunch pipe

図 7 配管の断面図

Fig. 7. Cross sectional view of main and brunch pipes
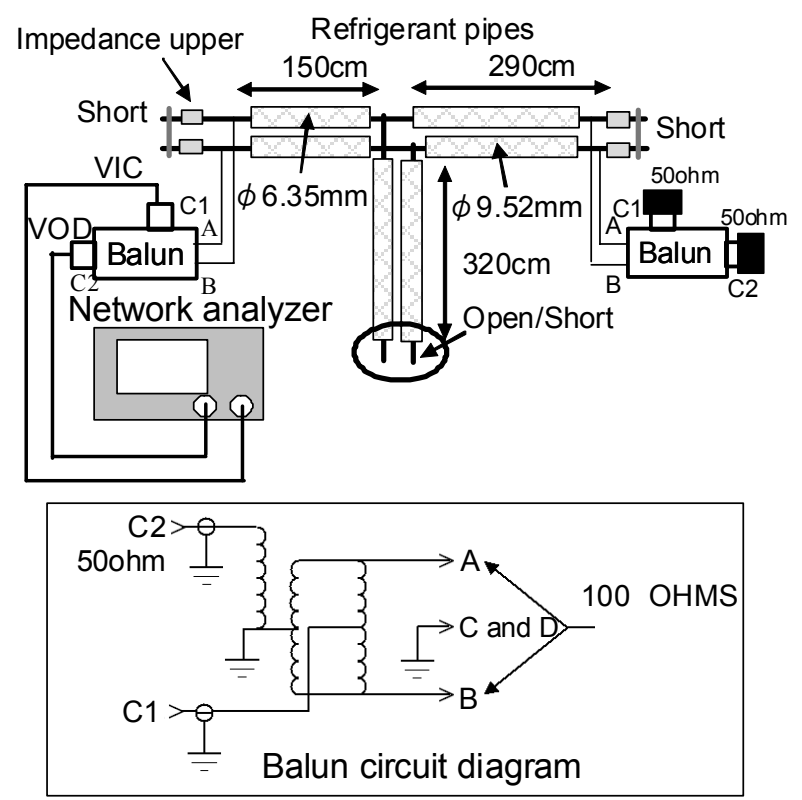

図 8 LCL 計測システムの構成

Fig. 8. Configuration of LCL measurement systems 

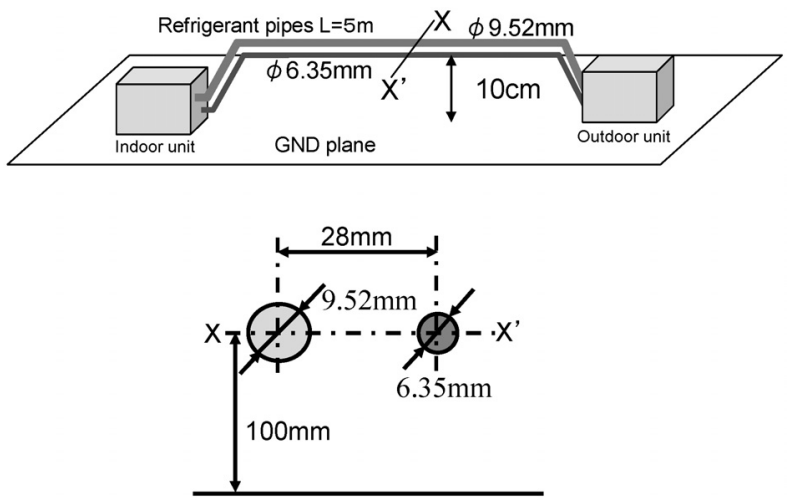

図 9 漏洩電界の計測モデル

Fig. 9. Pipe-based transmission line model for leaked electric field

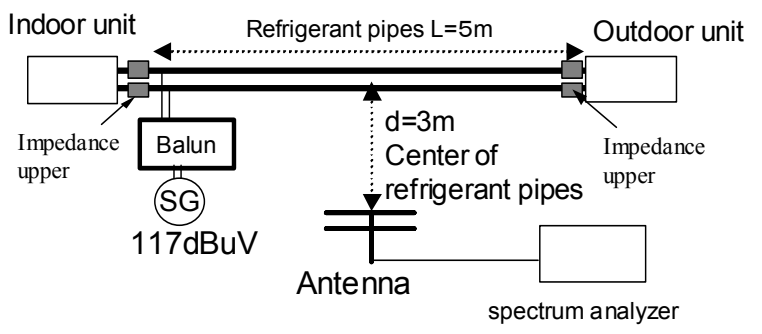

図 10 漏洩電界計測システムの構成

Fig. 10. Construction of leaked electric field measurement system

イン配管の両端はグランドプレーンに接続している。

HF 帯 PLC の帯域上限は 30MHz であるが，リファレンス モデルが総延長 $7.6 \mathrm{~m}$ と短いため，長い線路での計算結果を 模擬的に評価するため, 10 倍の周波数である $300 \mathrm{MHz}$ まで 測定した。測定周波数範囲で計算值の一致が得られれば, リファレンスとしたモデルの 10 倍程度の長さを持つ線路で 同様な計算精度が得られていると見なすことができる。

〈3.3〉 漏洩電界の計測方法 $5 \mathrm{~m}$ の配管の両端に空調 機の室内ユニットならびに室外ユニットを接続し, モデル を構成した。また，配管の両端には図 4 に示した特性のイ ンピーダンスアッパを取り付けている。計測周波数は計測 に用いたバイコニカルアンテナの帯域である $30 \mathrm{MHz} \sim$ $300 \mathrm{MHz}$ とし，電波無響室内で計測した。アンテナは配管の 中央から垂直方向に距離 $3 \mathrm{~m}$ 離して設置し，その高さは $1 \mathrm{~m}$ とした。配管の高さは配管支持治具高さの $10 \mathrm{~cm}$ としてい る。図 9 に漏洩電界計測に用いたモデルの構成図を, 図 10 に計測システム構成を示す。

\section{4. 計測結果}

〈4·1〉 LCL 計測結果図 11 にCL の計測結果を示 す。分岐端が短絡（図 11 中, SHORT-Mes) と開放（図 11 中 OPEN-Mes）の計測值に於いて，いずれの条件でも平均的 に $25 \mathrm{~dB}$ 程度に収束している。 $20 \mathrm{MHz} \sim 40 \mathrm{MHz}$ 近辺に見ら れる特性のハンプは各々分岐端の条件により共振, 反共振

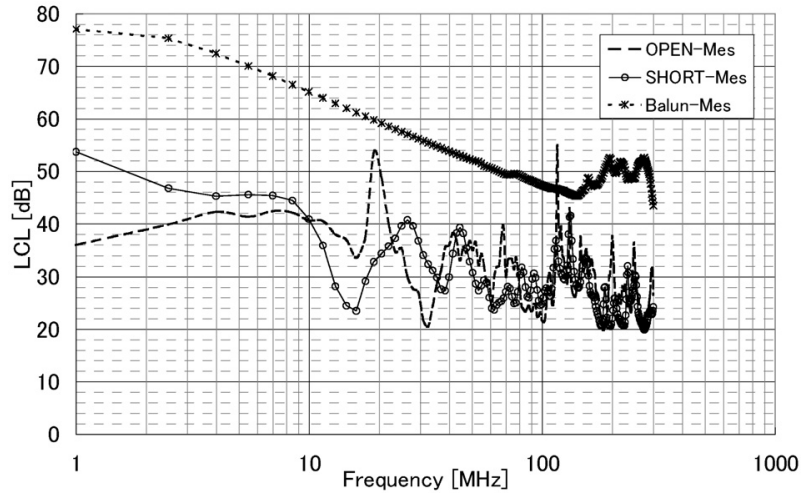

図 11 LCL 計測結果

Fig. 11. Measurement result of LCL

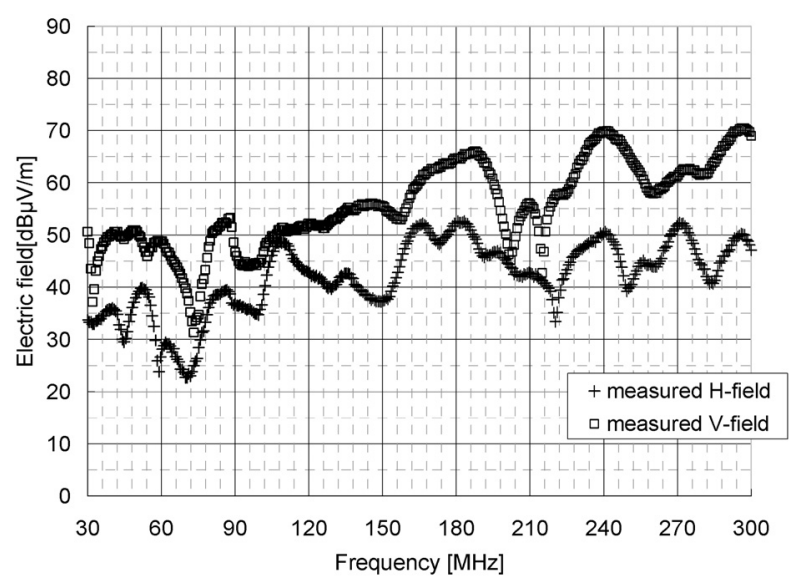

図 12 漏洩電界の計測結果（入力電圧 $117 \mathrm{~dB} \mu \mathrm{V}$ )

Fig. 12. Measurement result of radiated electric field

周波数にずれが生じている。分岐を有する計測モデルの配 管に於いて LCL 計測值は $20 \mathrm{~dB}$ 以上であった。また，計測 した LCL にはバランの不平衡分も含まれるため, バランの みの LCL 特性も掲載した。(図 11 中, Balun-Mes)

〈4·2〉漏洩電界計測結果図 12 は漏洩電界の計測結 果である。入力電圧を $117 \mathrm{~dB} \mu \mathrm{V}$ として測定している。また, 通常 $\mathrm{EMC}$ の評価では最大值を示すポイントを探して計測す るが，計算方法の妥当性評価に用いるデータ取得のため， アンテナの配置は室内ユニットと室外ユニットの中央に固 定し，配管鉛直方向の距離 $3 \mathrm{~m}$ に固定し計測を実施してい る。垂直偏波の電界が平均して $15 \mathrm{~dB}$ ほど水平偏波より高い 計測結果を得た。金属床表面上では，水平偏波の電界は原 理的に零になるが，垂直偏波では金属の影響を全く受けな い。そのため, 高さ $1 \mathrm{~m}$ の受信アンテナ周辺では, 金属床の 影響を受けない垂直偏波の電界が大きく現れ，上記のよう な計測結果が得られたものと推定できる。

\section{5. モーメント法による計算の妥当性検討}

〈5·1〉 LCL 計算モデルＬCL はモーメント法ソフト ウェア「NEC-WIN pro」を用いた。図 6 に示した計測モデル をモーメント法モデルに変換し，計算用のモデルを作成し 
た。

図 13 は配管を用いた伝送システムの伝送系等価回路であ る。バランを用いた信号印加部はコモンモードインピーダ ンス Z $\mathrm{CT}$ ，ディファレンシャルインピーダンス $\mathrm{Zs}_{\mathrm{s} 1}, \mathrm{Z}_{\mathrm{s} 2}$ と信号 源で構成される。インピーダンスアッパ ZTs1,ZTS2 は配管で 構成される線路と接地（GND）間に接続される。モーメン ト法の計算モデルでは, 信号印加部分を同図 13 示す様にデ イファレンシャルモードインピーダンスに等価近似し, 図 14 に示す解析モデルとした。インピーダンス Z Zsc1，Zsc2 を 各々

$$
\begin{aligned}
& Z_{\mathrm{SC} 1}=Z_{\mathrm{S} 1}+2 \mathrm{Z}_{\mathrm{CT}} \\
& \mathrm{Z}_{\mathrm{SC} 2}=\mathrm{Z}_{\mathrm{S} 2}+2 \mathrm{Z}_{\mathrm{CT}}
\end{aligned}
$$

とすると図 13 に示す線路電流 $\mathrm{I}_{\mathrm{C} 1}, \mathrm{I}_{\mathrm{C} 2}$ は $\mathrm{I}_{\mathrm{CM} 1} \fallingdotseq \mathrm{I}_{\mathrm{C} 1}, \mathrm{I}_{\mathrm{CM} 2}$ $\doteqdot \mathrm{I}_{\mathrm{C} 2}$ と近似できる。このように伝送系等価回路を $\mathrm{Z}_{\mathrm{SC} 1}, \mathrm{Z}_{\mathrm{SC} 2}$ により単純化したモデルを構成した。

LCL は，コモンモードの信号に対するディファレンシャ ルモード信号への入力端における変換比なので，コモンモ ード入力を模擬するために, 図 14 に示す 2 本のワイヤの給 電点において同相で電圧を印加した。この印加された同相 電圧のうち，ワイヤ上の電流は配管径の違いによる影響を 受け，その位相や振幅が変化する。したがって，2 線の入力 端のセグメントにおける複素電流を減算しても, 完全には 0 にはならずに，いくらかの成分を持つ。この電流を印加し たコモンモード電流から変換されたディファレンシャルモ ードの電流として考え, ディファレンシャルモードインピ ーダンスとの積をとることにより，ディファレンシャルモ ード電圧 VOD を得る。

図 14 に作成した LCL の計算モデルを示す。 $\mathrm{Z}_{\mathrm{SC} 1}, \mathrm{Z}_{\mathrm{SC} 2}$ の 内, コモンインピーダンス分が $130 \Omega$, ディファレンシャル インピーダンス分が $50 \Omega$ で計 $180 \Omega$ とした。ディファレン シャルインピーダンス Zs1，Zs2 はバランのディファレンシ ヤルインピーダンスカタログ值 $100 \Omega$ を 2 分割したものであ る。また, コモンインピーダンス Zct はネットワークアナラ イザで計測した值を用いている。また $\mathrm{Z}_{\mathrm{TS} 1}, \mathrm{Z}_{\mathrm{TS} 2}$ は図 4 の特 性を基に算出したインピーダンスアッパに相当する RL 直 列等価回路（ $\mathrm{R}=85 \Omega, \mathrm{L}=0.25 \mu \mathrm{H})$ により構成した。また, 受信側も同様な構成，ならびにパラメータとしている。

図 15 に信号印加部の構成を示す。送信点の電流 I1 ならび に I2 を計算し，(3)式により送信点の合成インピーダンス である $\mathrm{Z}_{\mathrm{SC} 1}$ と $\mathrm{Z}_{\mathrm{TS} 1}$ の並列インピーダンス $\mathrm{Z} 1(=\mathrm{Z} 2)$ を各々乗 算した後に複素減算して不平衡により生じるディファレン シャル電圧 VOD を計算した。また, LCL は入力電圧 VIC と VODの比を取り，(4)式により計算した。

$$
\begin{aligned}
& \mathrm{VOD}=\mathrm{Z} 1 \times \mathrm{I} 1-\mathrm{Z} 2 \times \mathrm{I} 2 \ldots \ldots \ldots \\
& \mathrm{LCL}=20 \log (\mathrm{VIC} / \mathrm{VOD})
\end{aligned}
$$

図 16 はインピーダンスアッパのインピーダンス絶対值特 性と等価回路インピーダンス計算值の比較図である。 $100 \mathrm{MHz} \sim 300 \mathrm{MHz}$ で誤差が大きくなっているが $1 / 10$ モデル における DTPLC モデムの使用周波数（2MHz〜 $10 \mathrm{MHz})$ に 相当する帯域の $20 \mathrm{MHz} \sim 100 \mathrm{MHz}$ での再現性を優先したパ
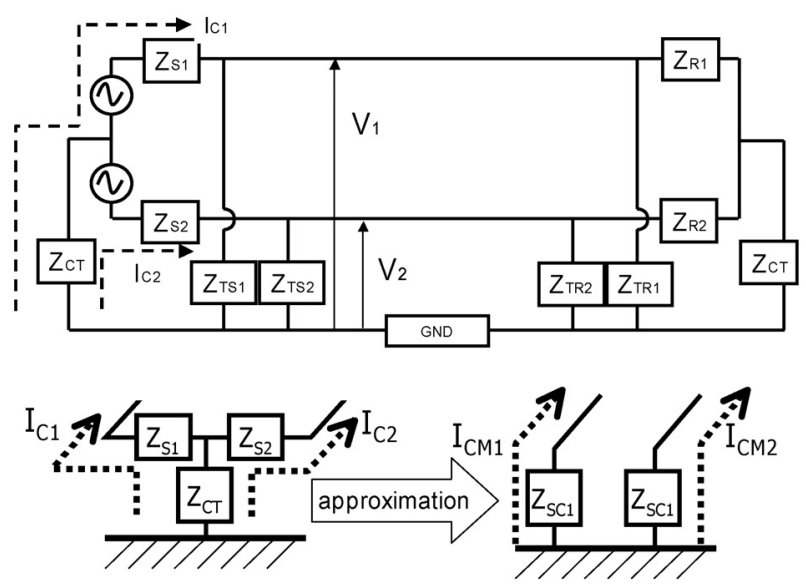

図 13 伝送系の等価回路と信号印加部の近似モデル

Fig. 13. Equivalent circuit diagram of the transmission line and approximate model of the input balun

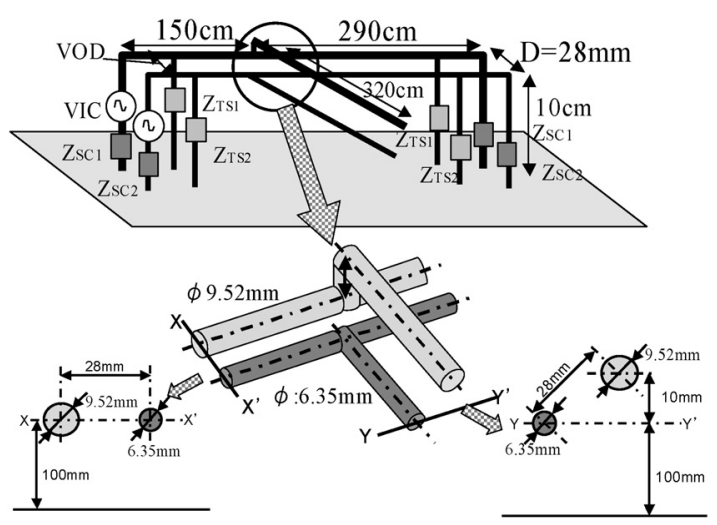

図 14 LCL の計算モデル

Fig. 14. LCL calculation model

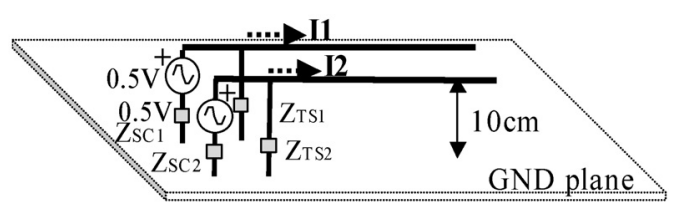

図 15 LCL 計算モデルの信号印加部における構成

Fig. 15. Detail of the transmission port

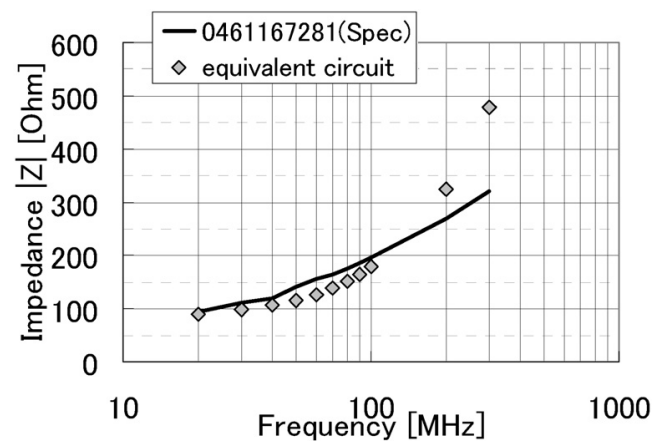

図 16 インピーダンスアッパと等価回路特性

Fig. 16. Frequency characteristic of the impedance upper and equivalent circuit 


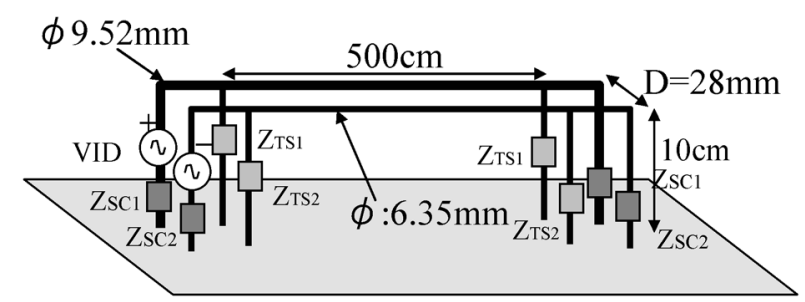

図 17 漏洩電界計算モデル

Fig. 17. calculation model of the leaked electric field

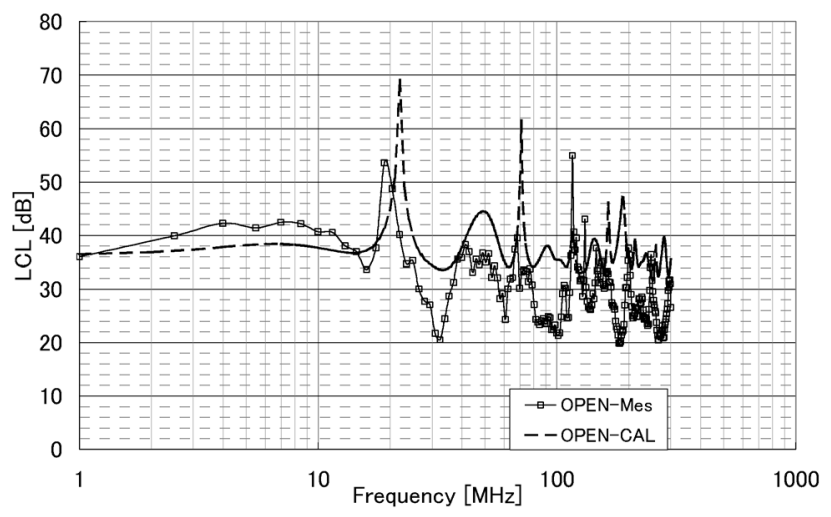

図 18 LCL 計算結果及び計測結果の比較（分岐端：開放）

Fig. 18. Calculation result of LCL (branch condition open)

ラメータを採用することとした。

図 17 は漏洩電界の計算モデルである。図 9 に示した漏洩 電界計測モデルをモーメント法のモデルに変換している。 信号印加点の詳細は信号電圧をディファレンシャルとして いる以外は図 15 と同様である。電界の計算位置は計測モデ ルと同様に，配管中央から $3 \mathrm{~m}$ の距離で, 高さ $1 \mathrm{~m}$ の地点で 行った。

〈5·2〉 LCL 計算結果 LCL に関して分岐端が開放状 態での計算結果と計測值を図 18 に示す。分岐端が開放条件 であるため低周波域から配管径のアンバランスの影響を受 け, LCL が約 $40 \mathrm{~dB}$ 程度と短絡条件に比較して低い傾向や, 分岐路の共振と思われる $20 \mathrm{MHz} \sim 70 \mathrm{MHz}$ 近辺に現れるピー クは比較的良く再現されている。高域に行くに従い，細か な共振，反共振周波数のずれなど課題はあるが，全体的な LCL-周波数特性の傾向は比較的良く再現されている。また, 分岐端が短絡状態での計算結果と計測值を図 19 に示す。分 岐端が短絡条件であるため，低周波数域においては配管径 のアンバランスに因り発生するディファレンシャルモード 電圧は小さく, $1 \mathrm{MHz} \sim 10 \mathrm{MHz}$ の低周波域において LCL が 開放条件より良くなり, 約 $55 \mathrm{~dB}$ から右下がりの特性を示す 傾向や，高域での細かな共振，反共振周波数のずれなど課 題があるものの，10MHz 以上で発生するハンプの傾向は比 較的良く再現されており，全体的な LCL-周波数特性の傾向 は比較的良く再現されている。このように分岐端の条件の 違いによる特性の違いの特徵などは再現されており，配管 を用いた伝送システムにおいてモーメント法で LCL 計算を 行うことの可能性が確認できた。

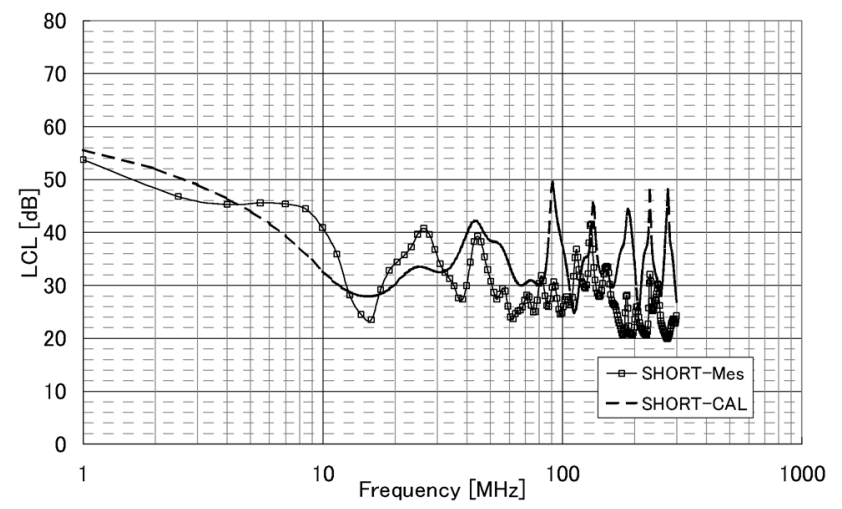

図 19 LCL 計算結果及び計測結果の比較（分岐端：短絡）

Fig. 19. Calculation result of LCL (branch condition short)

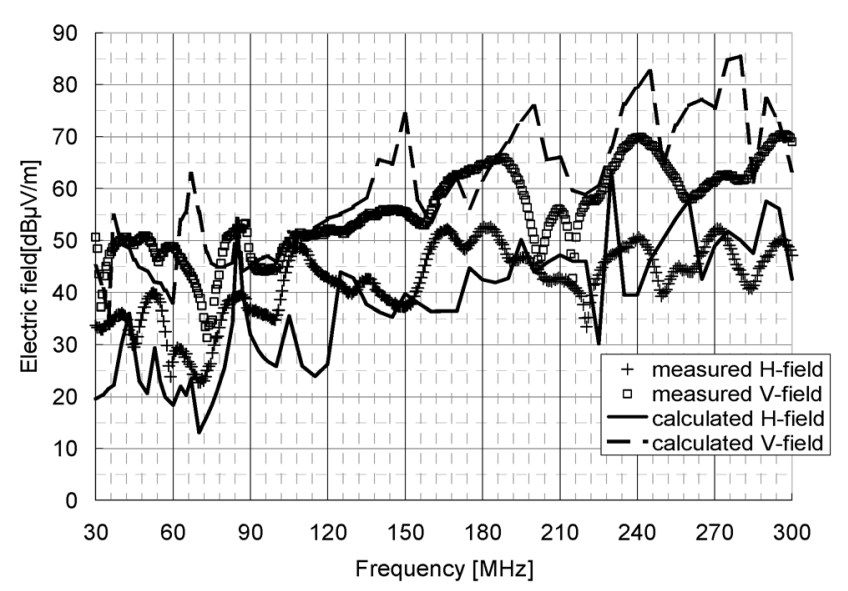

図 20 漏洩電界の計算結果

Fig. 20. Calculation result of leaked electric field

〈5·3〉漏洩電界計算結果図 20 に漏洩電界の計測結 果と計算結果を示す。計算結果においては周波数が高くな るに従い, 垂直偏波と垂直偏波の平均的なレベル差が若干 大きくなる傾向があるものの，計測值と同様に垂直偏波の 漏洩電界が水平偏波より平均的に見て約 $15 \mathrm{~dB}$ 程度大きくな る特徵, 全体的なレベルが右上がりになる傾向などが再現 されている。共振, 反共振によるハンプの周波数のずれや 最大で約 $20 \mathrm{~dB}$ 程度の誤差があるなど課題はあるが, 全体的 な特性の傾向は比較的良く再現されている。

以上のようにモーメント法を用いて, 基本的な EMC 特性 である線路の平衡度 (LCL) ならびに漏洩電界について配管 を用いた伝送システムの評価についての可能性が確認でき た。次章からはモーメント法を用いた実用規模の配管シス テムにおける漏洩電界の評価について述べる。

\section{6. 実用規模システムにおける EMC 特性のシミュ レーション}

〈6・1〉 評価対象モデムの仕様 図 21 に DTPLC 方式 (6)のモデム LSI の外観を示す。本モデム LSI は制御用途を 中心に仕様が検討された HF 帯 PLC モデム LSI である。既 存の無線局等との干涉を避けるためキャリア周波数を 


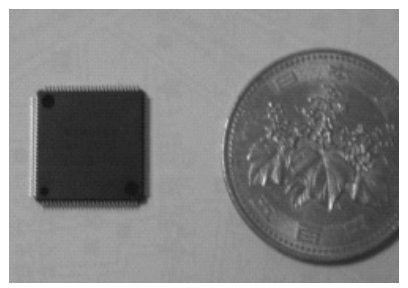

図 21 DTPLC 方式モデムの LSI 概観

Fig. 21. View of the modem LSI of DTPLC system

表 1 DTPLC 方式モデムの LSI 仕様

Table 1. Specification of the modem LSI of DTPLC system

\begin{tabular}{|l|l|}
\hline \multicolumn{1}{|c|}{ Item } & \multicolumn{1}{c|}{ Specification } \\
\hline Modulation & $\begin{array}{l}\text { Dispersed-Tone multi carrier } \\
\text { DQPSK/DBPSK }\end{array}$ \\
\hline Transmission speed & $400 \mathrm{kBPS}(\max )$ \\
\hline Carrierfrequency[MHz] & $2.56 / 5.12 / 6.4 / 7.68 / 8.96$ \\
\hline
\end{tabular}

2.56/5.12/6.4/7.68/8.96MHz に分散させたトーン分散型マル チキャリア方式を採用している。また， 1 次変調方式には DQPSK (Differential Quadrature Phase Shift Keying) と DBPSK (Differential Binary Phase Shift Keying) を採用しており，1 ーンあたりの伝送速度は DQPSK 時に $80 \mathrm{kbps} ，$ DBPSK 時に $40 \mathrm{kbps}$ である。各トーンに異なるデータをマッピングする Differential モードと,よりロバスト性を高くするためにす心゙ てのトーンに同じデータをマッピングする Same モードを 有し, 伝送速度は最大 400kbps (Differential モード, 80kbps $\times 5$ ), 伝送品質に応じて 40kbps (Same モード, $40 \mathrm{kbps} \times 1$ ) までフォールバック処理を自動で行う(7)。表 1 にDTPLC 方 式モデムの LSI 仕様を示す。また，図 22 には本モデムの減 衰量に対する PER の評価結果を示す。表に示すように送信 出力はトーン当たり $99 \mathrm{~dB} \mu \mathrm{V}($ at $50 \Omega)$ としている。評価の 結果，限界性能の確認はできていないが，70dB の減衰量ま で許容可能である。図 5 に例示した様に, ビルに設置され た空調システム配管の減衰量は $44 \mathrm{~dB}$ 程度のため, このモデ ムの減衰許容性能の範囲であり，実用レベルとして十分な 通信品質を得ることが可能である。以降，このモデムの出 カレベル $99 \mathrm{~dB} \mu \mathrm{V}$ を前提に漏洩電界の計算を実施すること とする。

〈6·2〉漏洩電界計算モデル 図 23 は 2 章で減衰特性 を示したビルの空調配管図面を基に作成した実用規模の配 管モデルである。4階建て相当の建物に設置された空調シス テムを想定し，総延長 $160 \mathrm{~m}$ ，各階間 $5 \mathrm{~m}$ 間隔で $40 \mathrm{~m} ， 30 \mathrm{~m}$ $\times 2 ， 35 \mathrm{~m}$ の分岐を持つ構成とした。また，床ならびに壁の 鉄骨をアースと見なし，平面の GND プレーンから $1 \mathrm{~m}$ の距 離に配管を配置した。信号印加部の詳細を図 24 に示すが, 送信端（TX）にはモデム出力である $99 \mathrm{~dB} \mu \mathrm{V}$ のディファレ ンシャル電圧を 2 分割した電圧 $44.5 \mathrm{mV}$ を各線に印加してい る。また，図 25 には各分岐端の詳細を示す。眓の様にイン ピーダンスアッパ相当のインピーダンスを直列に挿入して グランドプレーンに接続している。また配管の高さはグラ

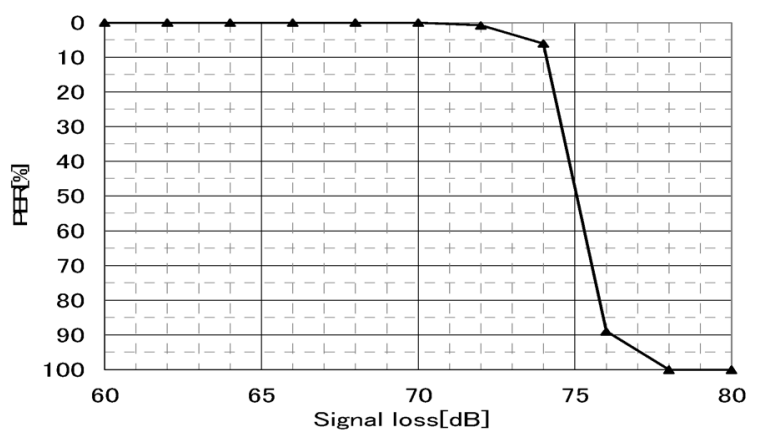

図 22 減衰量一PER(パケットエラーレート)性能評価結果 Fig. 22. PER performance with transmission loss

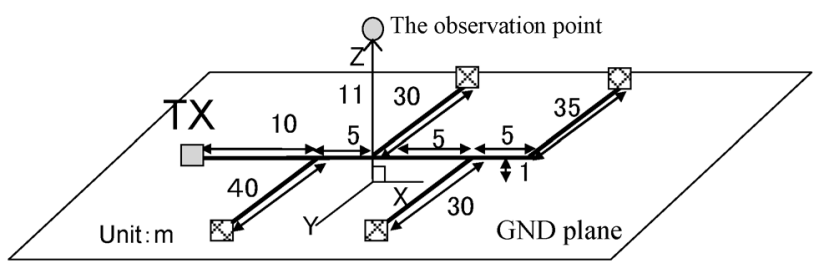

図 23 実用規模空調配管に対する漏洩電界評価モデル

Fig. 23. Air-conditioner pipes maximum size model for evaluating the leaked electric field

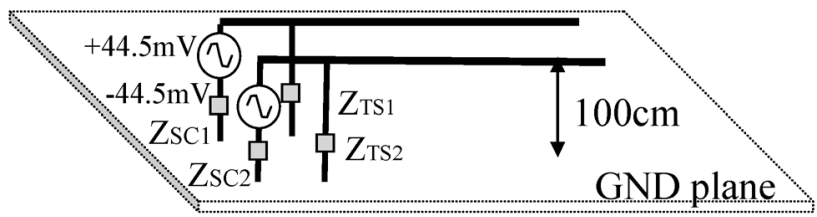

図 24 信号印加部の詳細

Fig. 24. Detail of transmission port

ンドプレーンから $1 \mathrm{~m}$ の高さとした。

計算を実施する周波数の範囲は実寸法のモデルであるこ とを考慮し, HF 帯 PLC の信号帯域をカバーする $1 \mathrm{MHz} \sim$ $30 \mathrm{MHz}$ とした。また, 電界計算の位置は各配管からの漏洩 電界が集中すると思われるモデルのほぼ中央となるメイン 配管 TX 端から長手方向に $15 \mathrm{~m}$, 高さ $11 \mathrm{~m}$ とし, 配管から の距離を $10 \mathrm{~m}$ の位置とした。

〈6·3〉計算結果の検討図 26 に漏洩電界の計算結果 を示す。計算は中心点から $\mathrm{Y}$ 方向に $\pm 1 \mathrm{~m}$ 間隔の 3 点で実施 し, その平均值をプロットしたものである。本モデルの最 長分岐路が $40 \mathrm{~m}$ であり， $1 / 4$ 波長に相当する周波数は約 $1.87 \mathrm{MHz}$ である。図 26 に示寸計算結果では $1.6 \mathrm{MHz} \sim 1.7 \mathrm{MHz}$ 近辺で第 1 のピークが発生しており，この発生要因が $40 \mathrm{~m}$ の最長分岐路であると推察できる。この周波数以下では共 振の発生は無いために単調なカーブ特性となり，1.6 MHz 以 上の周波数では他の分岐路の 1 次共振や各分岐路の高次共 振によるものと思われる放射レベルの急激な変化が見られ る。また, 水平偏波, 垂直偏波相互で大きなレベル差は見 られない。

図 27 には配管の高さならびに GND 条件を変えた場合の 


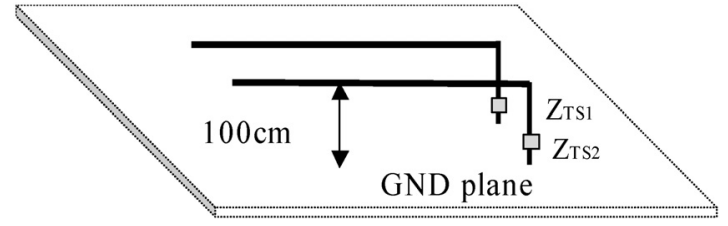

図 25 分岐端の詳細

Fig. 25. Detail of branch end

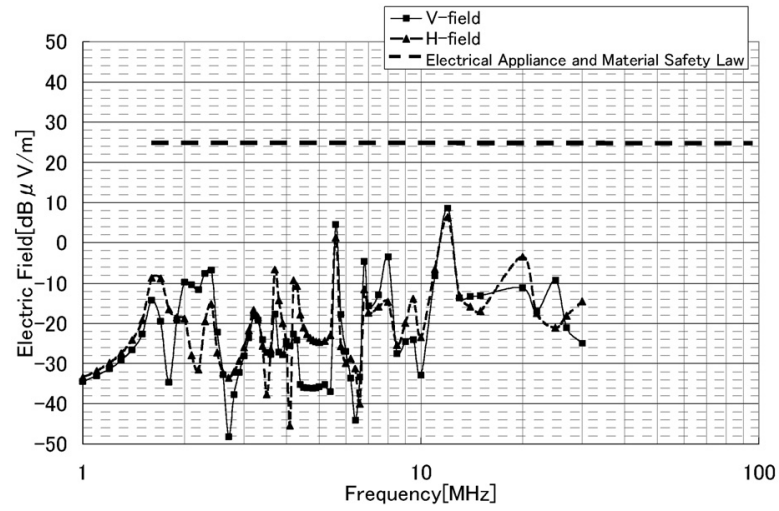

図 26 実用規模モデルの漏洩電界計算結果

Fig. 26. Calculation result of leaked electric field in the maximum model

垂直偏波の漏洩電界計算結果を示す。 $10 \mathrm{MHz}$ 以下では配管 高さ $1 \mathrm{~m}$ に比較して高さが増加するに従い漏洩電界レベル の増加が見られ，GNDを自由空間とした条件で最大 $7 \mathrm{~dB}$ の 増加が見られ，また，ピーク值では $5.6 \mathrm{MHz} て ゙ ~ 7.5 \mathrm{~dB} \mu \mathrm{V} / \mathrm{m}$ であり $1 \mathrm{~m}$ の条件に比較して約 $2.5 \mathrm{~dB}$ の増加が見られた。 $10 \mathrm{MHz}$ 以上では条件による顕著な差異は見られないが，ピ ークレベルとしては高さの条件を $0.5 \mathrm{~m}$ にした場合に， $12 \mathrm{MHz}$ 近辺で約 $2.5 \mathrm{~dB}$ の増加が見られた。

表 2 に配管組み合わせの代表例を示す。配管径の比率は 0.5 0.67 程度の範囲で組み合わされている。図 28 は表 2 に 示した配管系の比率 R が 0.5，0.6，0.67 について配管長 $10 \mathrm{~m}$ の各ペアに対する LCL の計算結果を示したものである。

LCL の変化幅は高域になるほど大きくなっておりその差は 約 3dB であった。LCL に比例し放射電界も増加すると仮定 し, 配管径比最大の 0.5 の場合に放射電界は $3 \mathrm{~dB}$ 増加するこ とが予測できる。

計算結果において電界強度の最大值は $10 \mathrm{~dB} \mu \mathrm{V} / \mathrm{m}$ 程度で あった。モデムのキャリア周波数範囲である $10 \mathrm{MHz}$ 以下で は最大 $5 \mathrm{~dB} \mu \mathrm{V} / \mathrm{m}$ 程度であった。ビル用マルチエアコンや住 宅用エアコンなどと同一フィールドに多く設備される機器 として電気用品安全法, 別表第八 $2(86$ の 6) で規定される 「蛍光ランプ」の規制值「距離 $10 \mathrm{~m}$ において $1,650 \mathrm{kHz}$ を超 え $30 \mathrm{MHz}$ 以下において $25 \mathrm{~dB} \mu \mathrm{V} / \mathrm{m} 」$ を参考值として比較し た場合，20dB のマージンはある。ただし，本計算結果には $\langle 5 \cdot 3\rangle$ 節に示した $1 / 10$ モデルの計算誤差と同等の誤差の $20 \mathrm{~dB}$ と高さ条件による $2.5 \mathrm{~dB}$ の増加ならびに配管径比最大 0.5 での $3 \mathrm{~dB}$ の増加を考慮すると, 規定值を数 $\mathrm{dB}$ 超える可

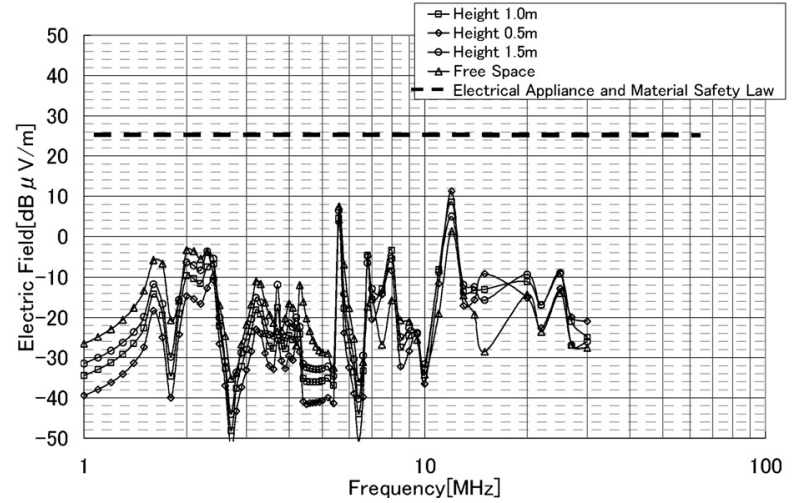

図 27 配管高さ GND 条件と漏洩電界 （垂直偏波）計算結果

Fig. 27. Calculation result of leaked Vertical electric field with pipes height and ground condition

表 2 配管組み合わせ例

Table 2. Ratio of the pipe pair

\begin{tabular}{|r|r|r|l|}
\hline $\begin{array}{c}\text { Requid } \\
\text { pipe }\end{array}$ & $\begin{array}{r}\text { Gas pipe } \\
\varphi[\mathrm{mm}]\end{array}$ & $\begin{array}{r}\text { Requid/Gas } \\
\text { ratio }\end{array}$ & \multicolumn{1}{c|}{ application } \\
\hline 6.35 & 9.5 & 0.67 & room/multi air conditioner for residential \\
\hline 6.35 & 12.7 & 0.50 & multi air conditioner for store \\
\hline 9.52 & 15.88 & 0.60 & multi air conditioner for building \\
\hline 9.52 & 19.05 & 0.50 & \\
\hline 12.7 & 19.05 & 0.67 & \\
\hline 15.88 & 31.75 & 0.50 & \\
\hline \multicolumn{3}{|c|}{} \\
\hline
\end{tabular}

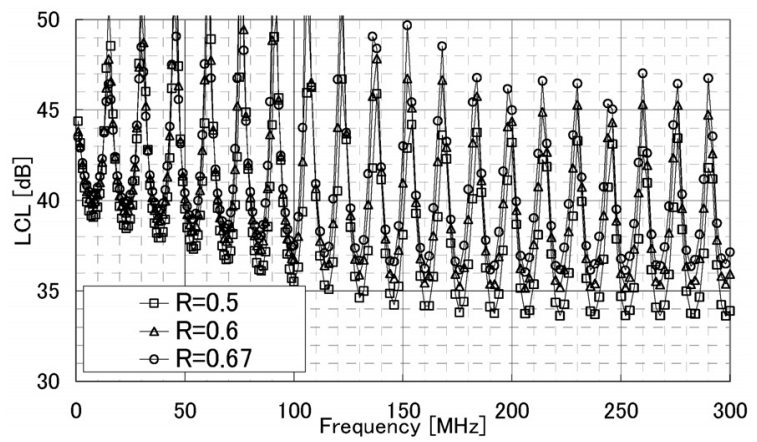

図 28 配管径比率 - LCL 計算值

Fig. 28. Calculation result of LCL with ratio of the pipe pair

能性があり，実際にはモデムの出力調整などの対応が必要 になる可能性がある。また，参考として，電波法施行規則 第四十四条, 第二項に記載の広帯域電力線搬送通信設備の 規制值と比較検討した。この規制值は伝導妨害波の電流值 としてコモンモード準尖頭值電流で規制されており $\mathrm{Ic}=$ $30 \mathrm{~dB} \mu \mathrm{A}($ at $2 \mathrm{MHz} \sim 15 \mathrm{MHz}), 20 \mathrm{~dB} \mu \mathrm{A}($ at $15 \mathrm{MHz} \sim 30 \mathrm{MHz})$ とされている。この值の内厳しい方の值である $\mathrm{I}=20 \mathrm{~dB} \mu \mathrm{A}$ として $10 \mathrm{~m}$ 地点での電界に換算する。

ビオサバールの法則より $\mathrm{H}=\mathrm{Ic} / 2 \pi \mathrm{R}$ であるので

$\mathrm{R}=10 \mathrm{~m}$ として $\mathrm{H}=-15.96 \mathrm{~dB} \mu \mathrm{A} / \mathrm{m}$

$\mathrm{E}=\mathrm{H} \mathrm{dB} \mu \mathrm{A} / \mathrm{m}+20 \log 376.7 \Omega$ より

$\mathrm{E}=35.56 \mathrm{~dB} \mu \mathrm{V} / \mathrm{m}$ となる。図 26 に示した計算值はピーク で $10 \mathrm{~dB} \mu \mathrm{V} / \mathrm{m}$ であり，規制值より低い值を示した。また， LCL は $16 \pm 3 \mathrm{~dB}$ として広帯域電力線搬送通信設備に於いて 
規定されている。図 11 に示したように本検討の範囲では配 管の LCL は $20 \mathrm{~dB}$ 程度であった。従って, 空調配管を用い た伝送システムは広帯域電力線搬送通信設備と同等の EMI 性能を実現可能であることが推察できる。

モデムの許容減衰量 $70 \mathrm{~dB}$ と比較して, 図 5 に例示した様 に，ビルに設置された空調システム配管の減衰量は $44 \mathrm{~dB}$ 程 度のため, 出力の調整は可能であり, 規定值以下に収まる 可能性は十分にある。このように計算結果から配管伝送シ ステムと HF- DTPLC モデムの組み合わせに於いて実用的な EMI 性能を保有する可能性のあることが確認できた。

\section{7. むすび}

無線ネットワークを補完する伝送媒体として空調などの 金属配管を用いる配管伝送システムに対する LCL と漏洩電 界を実験的理論的に検討した結果，以下の諸点が明らかに なった。

（1）導体の径がアンバランスな分岐を有する配管伝送 システムの LCL 計測值は分岐端条件の開放と短絡に於いて $20 \mathrm{~dB}$ 以上であった。分岐端が開放の線路は短絡の線路に比 較して，低域において LCL が悪化する傾向を示した。

(2) LCL, 漏洩電界について計測值と計算值を比較し, モーメント法による配管伝送システムの計算に対する可能 性を示した。

（３）実用規模の配管モデルについて，モデムの出力であ る $99 \mathrm{~dB} \mu \mathrm{V}$ 印加時の漏洩電界を計算した結果，電気用品安 全法で規定された EMI 規制值を満足する可能性のある伝送 システムであることを示唆した。また，電波法施行規則第 四十四条，第二項に記載の広帯域電力線搬送通信設備の規 制值（コモン電流 $20 \mathrm{~dB} \mu \mathrm{A}$ ） から電界強度に換算した值と 比較した結果，同様に規定值以下の EMI 值となる可能性が ある。

以上により，配管を用いた伝送システムが電磁環境適合 性を持つ可能性がある伝送媒体であることを明らかにし た。

(平成 19 年 11 月 21 日受付，平成 20 年 4 月 14 日再受付)

\section{文献}

(1) M. Nakata, N. kushiro, T. Higuma, and N. Hibara : "Ubiquitous Network for Building and Home control With Ad-hoc Wireless and Plug \& Play mechanism”, Ubicomp2005, September, pp.11-14 (2005)
(2) T. Higuma, N. kushiro, M. nakata, Y. Watanabe, and M. Tokuda : "Transmission loss and radiated electric field characteristics of transmission medium for ubiquitous network" ICCE2007 Digest of technical paper. pp.2-6 (2007-1)

( 3 ) M. Tokuda : "High Speed PLC (Power Line Communication)", The IEICE JOURNAL Vol.88, No.3 (2005-3)

(4) Y. Watanabe, H. Shiozawa, and M. Tokuda : "Calculation of Radiated Emissions from Power Line with Four Port Network Theory", IEEJ Trans. $F M$, Vol.125, No.10 (2005)

（5）渡邊陽介・徳田正満・牧 昌弘：「分岐のある電力線モデルの平衡度 と漏洩電界に対するモーメント法計算」，信学技報，EMCJ, (2005-9)

(6) H. Kubota, K. Suzuki, I. Kawakami, M. Sakugawa, and H. Kondo : "High Frequency Band Dispersed-Tone Power Line Communication Modem for Networked Appliances", IEEE Transactions on Consumer Electronics, Vol.52, No.1 (2006)

(7) http://www.cepca.org/about_us/Events/past_events/japan_seminar/CEPCA_ Seminar_Renesas.pdf

（8）「直膨式マルチエアコンシステム新冷媒シリーズシステム設計・エ 事マニュアル」，P14，MEE02W112，三菱電機

(9) 15th_Edition_Fair-Rite_Catalog,

http://www.fair-rite.com/newfair/pdf/15th Edition Fair-Rite Catalog.pdf, 2005

樋 熊 利 康 (非会員) 1978 年金沢工業大学・工学・電子卒

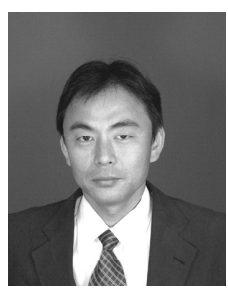
業, 現在, 三菱電機（株）住環境研究開発セン ターに在籍。主として住宅・ビル設備機器用ネ ットワークシステムの開発に従事。武蔵工業大 学大学院工学研究科博士後期課程在学中。

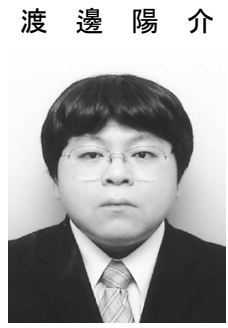

（学生員）２０03 年武蔵工業大学電子通信工学科 卒業。同年, 同大学大学院工学研究科修士課程 に進学。2005 年修士課程卒業。同年, 博士課程 に進学。現在, 在学中。主に電力線搬送通信シ ステムなど通信システムの研究に従事。

徳 田 正 満 (正員) 1967 年北大・工・電子卒業。1969 年

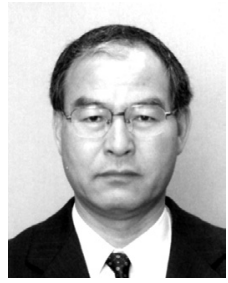
同大学大学院修士課程修了。同年日本電信電話 公社に入社。以来, 光ファイバケーブル伝送特 性測定法，通信装置の EMC 等の研究に従事。 1996～2001 年まで，九工大・電気・教授。現在， 武蔵工業大学・電子通信工学科教授。工博。電 力線搬送システムや無線通信システムなど通 信システムの研究に従事。2007 年 IEEEフェロ 一。IEC TC77（EMC）国際議長。 